\title{
Extrauterine growth restriction: Universal problem among premature infants
}

\author{
Restrição de crescimento extrauterino: problema \\ universal entre os prematuros
}

\author{
Brunnella Alcantara Chagas de FREITAS \\ Silvia Eloiza PRIORE \\ Luciana Moreira LIMA' \\ Sylvia do Carmo Castro FRANCESCHINI ${ }^{1}$
}

\section{A B S T R A C T}

\section{Objective}

To analyze the growth rate of premature infants in the first weeks of life and factors associated with extrauterine growth restriction.

\section{Methods}

This is a cross-sectional study of 254 premature infants in a neonatal intensive care unit conducted from January 1, 2008 to December 31, 2010. Infants who died or had malformations incompatible with life were excluded. Median weight curves according to gestational age were constructed for the first four weeks of life. The Fenton growth chart calculations provided the weight Z-scores. Extrauterine growth restriction was defined as corrected weight-for-age Z-score $\leq-2$. Perinatal, morbidity, and health care variables were analyzed. The Poisson regression model yielded the prevalence ratios. Associations between extrauterine growth restriction and the perinatal, morbidity, and care variables were investigated. Poisson regression controlled possible confounding factors.

\section{Results}

The frequency of extrauterine growth restriction was $24.0 \%$. Most (85.0\%) small-for-gestational-age infants developed extrauterine growth restriction; $55.3 \%$ of extrauterine growth restriction cases involved small-forgestational-age infants. Premature infants with gestational age $>32$ weeks did not recover the median birth weight until the third week of life and had a higher frequency of small-for-gestational-age. The Z-scores of

\footnotetext{
1 Universidade Federal de Viçosa, Programa de Pós-Graduação em Ciência da Nutrição, Departamento de Medicina e Enfermagem. Av. P.H. Rolfs, s/n., Campus Universitário, 36570-900, Viçosa, MG, Brasil. Correspondência para/Correspondence to: BAC FREITAS. E-mail: <brunnella.freitas@ufv.br>.

2 Universidade Federal de Viçosa, Programa de Pós-Graduação em Ciência da Nutrição, Departamento de Nutrição e Saúde. Viçosa (MG), Brasil.

Article based on doctoral dissertation of BAC FREITAS, intitled "Restrição do crescimento extrauterino, amamentação e avaliação da adesão e influência da suplementação com micronutrientes nas prevalências de deficiências de ferro, zinco e vitamina A em prematuros". Universidade Federal de Viçosa; 2015.
} 
non-small-for-gestational-age infants decreased more after birth than those of small-for-gestational-age infants. extrauterine growth restriction was associated with small-for-gestational-age ( $\mathrm{PR}=6.14 ; 95 \% \mathrm{Cl}=3.33-11.33$; $p<0.001)$ and time without enteral diet ( $\mathrm{PR}=1.08 ; 95 \% \mathrm{Cl}=1.04-1.13 ; p=0.010)$.

\section{Conclusion}

Extrauterine growth restriction occurs in premature infants of all gestational age. The participation of small-forgestational-age and nutritional practices in its genesis is noteworthy. We suggest prospective studies of all premature infants. The implementation of best care practices, individualized for small-for-gestational-age infants, to improve nutrient supply can minimize the problem.

Keywords: Growth and development. Infant, premature. Malnutrition.

\section{RE S U M O}

\section{Objetivo}

Analisar o crescimento de prematuros nas primeiras semanas de vida e fatores associados à restrição de crescimento extrauterino.

\section{Métodos}

Estudo transversal realizado entre 01/01/2008 e 31/12/2010 com 254 prematuros em unidade de terapia intensiva. Excluirram-se óbitos e malformações incompatíveis com a vida. Construíram-se curvas de medianas de peso para as quatro primeiras semanas de vida de acordo com a idade gestacional. Calcularam-se escores-Z do peso pela planilha Fenton growth chart calculations. Definiu-se restrição de crescimento extrauterino pelos escores-Z do peso $\leq-2$ para a idade corrigida na alta hospitalar. Analisaram-se associações entre variáveis perinatais, assistenciais e morbidades com a restrição de crescimento extrauterino. Utilizou-se a regressão de Poisson para controlar os possiveis fatores de confundimento.

\section{Resultados}

A frequência de restrição de crescimento extrauterino foi de $24 \%$. Dos pequenos para a idade gestacional, $85 \%$ evoluíram com restrição de crescimento extrauterino. Prematuros com idade gestacional >32 semanas não recuperaram medianas de peso ao nascer até a terceira semana de vida, e, dentre eles, estava a maior frequência de pequenos para a idade gestacional. Os não pequenos para a idade gestacional apresentaram maior queda do escore-Z de peso do nascimento à alta quando comparados aos pequenos para a idade gestacional. Associaram-se à restrição de crescimento extrauterino nascer pequeno para a idade gestacional ( $R P=6,14 ;$ IC95\%=3,33-11,33; $p<0,001)$ e tempo sem dieta enteral $(R P=1,08 ; I C 95 \%=1,04-1,13 ; p=0,010)$.

\section{Conclusão}

A restrição de crescimento extrauterino ocorre entre prematuros de todas as idades gestacionais, ressaltando-se a participação do nascimento pequeno para a idade gestacional e das práticas nutricionais na sua gênese. Sugerem-se estudos prospectivos que envolvam todos os prematuros. A implementação de boas práticas assistenciais que visem melhorar a oferta nutricional e individualizada para os pequenos para a idade gestacional pode minimizar o problema.

Palavras-chave: Crescimento e desenvolvimento. Prematuro. Desnutrição.

\section{NTRODUCTION}

Extrauterine Growth Restriction (EUGR) in premature infants is an object of studies and results from a complex interaction between genetic and environmental factors, which affect nutritional requirements, endocrine disorders, and treatments ${ }^{1,2}$.

Growth involves genetic potentials that may or may not be reached, depending on the individual's life conditions from conception until adulthood. Prematurity is a determinant for stunting, with repercussions on adulthood ${ }^{3,4}$. Premature infants who are small for gestational age or with EUGR at hospital discharge are at greater risk of stunting and its long-term consequences ${ }^{1,2}$.

Morbidities that affect premature infants, such as hyaline membrane disease, prolonged ventilatory support, neonatal sepsis, bronchopul- 
monary dysplasia, and anemia, impact their postnatal growth ${ }^{3,5,6}$.

Extrauterine growth restriction is a marker of severe nutritional deficit during the first weeks of life, which can be assessed at 36 weeks of corrected age or at discharge based on reference intrauterine or postnatal growth curves ${ }^{3,7,8}$. Fenton \& $\mathrm{Kim}^{9}$ curves, which became available recently, are considered the standard postnatal growth curves $^{9-11}$. As gestational age and birth weight decrease, weight regain becomes harder, consequently increasing the incidence of EUGR. To decrease the incidence of EUGR and its consequences, protocols that improve the nutrient supply for premature infants, especially infants at higher risk, must be implemented and updated $^{12,13}$.

The survival of increasingly premature infants has resulted in many studies With VeryLow-Birth-Weight (VLBW) infants. However, there is a scarcity of studies with premature infants with a gestational age of 32 weeks or more, especially because $70 \%$ of premature infants have a gestational age of 34 weeks or more ${ }^{14}$.

In face of the above, the following questions arise: what is the growth rate of premature infants during the first weeks of hospital stay? How do gestational age, birth weight, and morbidities affect growth rate? What factors are associated with EUGR? Are there modifiable factors?

In order to answer these questions, this study assessed the growth rate of premature infants during the first weeks of extrauterine life and investigated the factors associated with extrauterine growth restriction at discharge from a Neonatal Intensive Care Unit (NICU).

\section{METHODS}

This cross-sectional, retrospective study used secondary data from the medical records of premature infants admitted to the NICU of the Hospital São Sebastião in Viçosa (MG) from January 1, 2008 to December 31, 2010.
The sample size was calculated by Stat Calc of Epi Info 7.0 (Centers for Disease Control and Prevention, Atlanta, Georgia, United States). A total of 140 premature infants would be needed for an EUGR prevalence of $26 \%{ }^{15}$, a power of $90 \%$, and a significance of $95 \%$.

The study included live premature infants with birth weight $>500 \mathrm{~g}$ and medical records with data from birth until discharge. Infants who died or had malformations incompatible with life were excluded. As a result, 254 premature infants were included.

Gestational age was obtained from the medical record and defined as the best estimate between early gestational ultrasound $(<20$ weeks), date of the last period, obstetric notes, and clinical examination using the New Ballard Score ${ }^{16,17}$. The corrected age was given by adding each week of postnatal life to the gestational age at birth ${ }^{3,18}$.

The medical records included the weights of the premature infants in the first four weeks of life (birth weight and on days 6, 13, and 27) and at discharge. The median weight $\left(50^{\text {th }}\right.$ percentile) for gestational age at birth and median corrected age at discharge were calculated, considering the number of completed weeks. Hence, curves of the median birth weight and weight at 6,13 , and 27 days of life were constructed.

Extrauterine growth restriction was defined as a weight-for-corrected age Z-score $\leq-2$ at discharge ${ }^{19}$, also considered the outcome variable. The weight Z-scores were calculated using the spreadsheet Fenton Growth Chart Calculations 9,20.

Birth weight and gestational age adequacy were given by the Fenton \& $\mathrm{Kim}^{9}$ curves, and the infants were classified according to birth weight Z-score. The infants were classified as appropriate for gestational age when birth weight Z-score >-1.29 $(10 \%)$ and small for gestational age when birth 
weight Z-score $\leq-1.29$ (10\%). The infants were also classified as appropriate for gestational age when they were between the tenth and ninetieth percentiles and large for gestational age when they were above the ninetieth percentile $e^{9,20}$.

Fenton \& $\mathrm{Kim}^{9}$ curves were used because they were based on a meta-analysis with the highest number of newborns to date and their respective data; the authors used the data to construct new curves for newborn growth assessment according to gestational age. According to the Portuguese Society of Pediatrics ${ }^{11}$, these curves approach a new standard curve. In addition to assessing fetal growth at birth, they allow monitoring the postnatal growth of premature infants until they reach a corrected age of 50 weeks as the data were harmonized with the World Health Organization ${ }^{21}$ curve from the $40^{\text {th }}$ week onward ${ }^{9,11}$.

Qualitative explanatory variables: gestational age was categorized according to the number of completed weeks: $<28$ weeks (extremely premature); between 28 and 31 weeks (very premature); and between 32 and 36 weeks (moderately premature) ${ }^{16}$; sex was categorized as female or male; and the small for gestational age variables bronchopulmonary dysplasia ${ }^{22}$, lateonset neonatal sepsis (occurring after the first 48 hours of life $)^{23}$, and transfusion of red blood cell concentrates were categorized in a binary fashion (yes/no).

Quantitative explanatory variables: gestational age (weeks and days); corrected age at discharge (weeks and days); birth weight and weight at discharge (grams); birth weight and weight at discharge Z-scores; length of hospital stay (days); duration of mechanical ventilation (days); total days of supplemental oxygen (days); age at start of enteral diet (days); age at start of parenteral nutrition (days); age at start of adequate enteral intake (days; considered as $150 \mathrm{~mL} / \mathrm{kg} /$ day) ${ }^{24,25}$; and days without enteral diet.

The study population was characterized by frequencies and measures of central tendency and dispersion. The Kolmogorov-Smirnov test showed that only the variables weight and weight Z-scores had normal distribution, so they were expressed as means and standard deviations. The other quantifiable variables were expressed as medians, $25^{\text {th }}$ percentile, and $75^{\text {th }}$ percentile. The qualitative variables were compared by the Pearson's Chi-square test or Fisher's exact test, and the quantitative variables by the Mann-Whitney, Kruskal-Wallis, or Student's $t$ tests.

Bivariate analyses were performed between the explanatory and outcome variables, obtaining, as a measure of effect, Prevalence Ratios (PR) using Poisson regression ${ }^{26}$. Variables with $p<0.20$ were included in multivariate analysis, and variables with $p<0.05$ were maintained in the final model.

The weight curves were constructed by adjusting a third-degree polynomial function to smooth the curves and thereby suppress small variations in their curvatures.

The programs Excel (Microsoft Office, Redmond, Washington, United States) version 2010, Stata (Stata Corporation, College Station, Texas, United States) version 9.1, and Statistical Package for the Social Sciences (SPSS Inc., Chicago, Illinois, United States) version 20.0, for Windows were used for creating the database, and codifying, entering, and statistically analyzing the data.

The study was approved by the Research Ethics Committee of the Universidade Federal de Viçosa, under Protocol no 063/2011, and did not require Signed Informed Consent. The study ensured the secrecy and confidentiality of all study participants' data.

\section{RES U L T S}

A total of 293 premature infants were eligible during the study period. However, 13.3\% of the premature infants $(n=39)$ died and were excluded from the study, resulting in a population of 254 premature infants. Table 1 characterizes the study population, which had an EUGR prevalence of $24.0 \%$. 
Table 1. Birth, hospital stay, and hospital discharge characteristics of premature infants. Viçosa (MG), Brazil, 2008-2010 ( $n=254)$.

\begin{tabular}{|c|c|c|c|c|c|c|}
\hline \multicolumn{7}{|c|}{ Birth } \\
\hline Variables & $n$ & $\%$ & Mean & SD & Median & $P_{25}-P_{75}$ \\
\hline \multicolumn{7}{|l|}{ Sex } \\
\hline Male & 145 & 57.1 & & & & \\
\hline Female & 109 & 42.9 & & & & \\
\hline \multicolumn{7}{|l|}{ Gestational age (weeks) } \\
\hline$<28$ & 21 & 8.3 & & & & \\
\hline $28-31$ & 75 & 29.5 & & & & \\
\hline $32-36$ & 158 & 62.2 & & & & \\
\hline \multicolumn{7}{|l|}{ Birth weight/gestational age* } \\
\hline Appropriate for gestational age & 203 & 79.9 & & & & \\
\hline Small for gestational age & 40 & 15.7 & & & & \\
\hline Large for gestational age & 11 & 4.3 & & & & \\
\hline Gestational age & & & -- & -- & 33.0 & $30.6-34.3$ \\
\hline Weight & & & $1,818.1$ & 648.6 & -- & -- \\
\hline Weight Z-score & & & -0.335 & 0.952 & -- & -- \\
\hline \multicolumn{7}{|c|}{ Hospital stay } \\
\hline Late-onset sepsis & 61 & 24.0 & & & & \\
\hline Bronchopulmonary dysplasia & 27 & 11.3 & & & & \\
\hline Transfusion of red blood cell concentrate & 84 & 33.1 & & & & \\
\hline Days of mechanical ventilation & & & & & 4.0 & $2.0-14.0$ \\
\hline Days of oxygen & & & & & 4.5 & $1.0-17.0$ \\
\hline Days at start of enteral diet & & & & & 2.0 & $1.0-4.0$ \\
\hline Days at start of parenteral nutrition & & & & & 3.0 & $2.0-4.0$ \\
\hline Days at start of adequate enteral intake & & & & & 15.0 & $9.0-22.5$ \\
\hline Days without enteral diet & & & & & 3.0 & $1.0-5.0$ \\
\hline
\end{tabular}

\section{EUGR}

$\begin{array}{lcc}\text { Yes } & 61 & 24.0 \\ \text { No } & 193 & 76.0\end{array}$

Corrected age

Weight

Weight Z-score

Days of hospital stay

\begin{tabular}{cccc}
-- & -- & 36.0 & $35.1-37.3$ \\
$2,209.3$ & 479.1 & -- & - \\
-1.332 & -1.132 & -- & -- \\
-- & -- & 18.0 & $9.0-40.0$ \\
\hline
\end{tabular}

Note: ${ }^{*}$ Classification based on the Fenton \& Kim ${ }^{9,10}$ curves. Results expressed as number (\%). The percentage of the categories refers to the total number of valid answers. Missing data were not considered.

SD: Standard Deviation.

Since the first weeks of life are an important time for growth, curves of the median weight of the premature infants were constructed according to their gestacional age at birth for the first four weeks of life (Figure 1).

The median birth weight tended to increase as gestational age increased. At six days of life, weight had decreased. At thirteen days, premature infants with gestacional age $<33$ weeks had regained their weight. However, a critical point appeared for premature infants with gestational age $>33$ : they had had no weight regain by the thirteenth or the twentieth day. At 27 days of life, premature babies with gestational age at birth $>33$ weeks had not yet regained their weight.

Bivariate analyses of the premature infants' characteristics from birth until NICU discharge were conducted, establishing EUGR as outcome (Table 2). The significant $(p<0.05)$ variables were: female sex, small for gestational age, late-onset sepsis, smaller measurements at birth and 


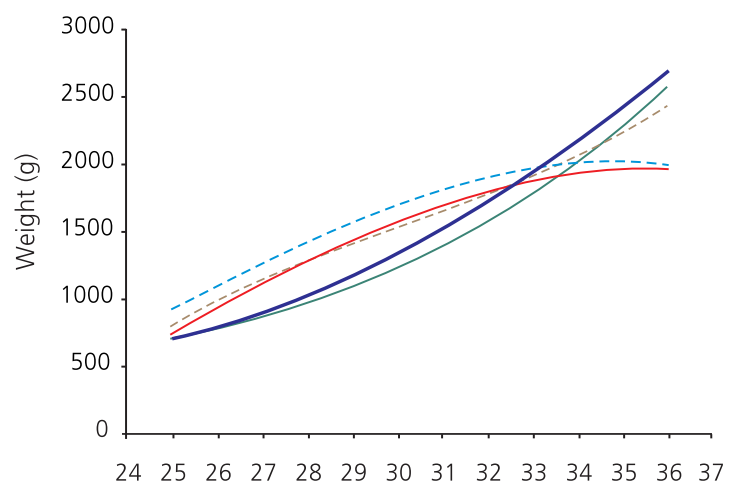

Gestational age (weeks)

$$
\begin{aligned}
& \text { - Birth weight }(p 50) \\
& - \text { Weight at } 13 \text { days }(p 50) \quad \text { - Weight at } 6 \text { days (p50) } \\
& - \text { Weight at } 20 \text { days (p50) } \\
& \text { Weight at } 27 \text { days (p50) }
\end{aligned}
$$

Figure 1. Median weight change per week on premature infants' first 27 days after birth according to gestational age at birth. Viçosa (MG), Brazil, 2008-2010

discharge, longer hospital stay, higher age at start of adequate enteral intake, and longer time without enteral diet.

These variables were submitted to bivariate Poisson regression for the outcome EUGR. The variables that persisted with $p<0.20$ were included in multivariate analysis: small for gestational age, sex, birth weight, neonatal sepsis, red blood cell concentrates, age at start of enteral diet, age at start of adequate enteral intake, and days without enteral diet. The variable gestational age was a confounding factor.

In the final regression model, the following variables remained associated with EUGR: small for gestational age at birth $(P R=6.14$; $95 \% \mathrm{Cl}=3.33-11.33 ; p<0.001)$ and days without enteral diet $(P R=1.08 ; 95 \% C l=1.04-1.13$; $p=0.010$ ) Table 3.

The variables small for gestational age at birth and days without enteral diet were analyzed by gestational age strata in an attempt to explain the behavior of the weight curves in Figure 1. Small for gestational age did not occur in premature infants with gestational age $<28$ weeks. Small for gestational age frequency was higher in the $\leq 32$ gestational age $\leq 36$ weeks' strata $(p=0.001)$. This occurred because the number of deaths increased as gestational age decreased ( $p<0.0001)$, and all small for gestational age $<28$ weeks died (data not shown). The variable days without enteral diet also differed by gestational age stratum $(p<0.0001)$ : time without diet decreased as gestational age increased (Table 3).

Most $(85.0 \%)$ of the infants born small for gestational age had EUGR at discharge, and $55.3 \%$ of the infants with EUGR were small for gestational age at birth. However, $44.3 \%$ of the EUGR were not small for gestational age. In a time line, $15.7 \%$ of the population was small for gestational age at birth, but $24.0 \%$ had EUGR at discharge.

Figure 2 shows how the mean weight Z-scores changed from birth to discharge in small for gestational age and non- small for gestational age infants. Small for gestational age infants had a mean weight Z-score of $-1.81( \pm 0.39)$ at birth and $-2.74( \pm 0.78)$ at discharge. Non- small for gestational age infants had a mean weight Z-score of $-0.06( \pm 0.75)$ at birth and $-1.07( \pm 0.98)$ at discharge.

The differences between the weight Z-scores at birth and discharge measured by the Student's $t$ test were significant for small for gestational age and non-small for gestational age infants $(p<0.0001)$ : the small for gestational age infants had a smaller weight Z-score loss (difference of 0.93), while non- small for gestational age had higher weight loss (difference of 1.01).

\section{ISCUSSION}

Extrauterine grown restriction between birth and a corrected age of 40 weeks is a proven risk factor for stunting and neurodevelopment deficit in the first two years of life $e^{3,27}$. Therefore, it is important to unveil the factors involved in EUGR genesis and intervene accordingly. 
Table 2. Characteristics of premature infants according to extrauterine growth restriction. Viçosa (MG), Brazil, $2008-2010$ ( $n=254)$.

\begin{tabular}{|c|c|c|c|c|c|c|c|c|c|}
\hline \multirow{3}{*}{ Variables } & \multicolumn{8}{|c|}{ Extrauterine growth restriction } & \multirow{3}{*}{$p$-value } \\
\hline & \multicolumn{4}{|c|}{ Yes } & \multicolumn{4}{|c|}{ No } & \\
\hline & \multicolumn{2}{|c|}{$n=61$} & \multicolumn{2}{|c|}{$\%$} & \multicolumn{2}{|c|}{$n=193$} & \multicolumn{2}{|l|}{$\%$} & \\
\hline Sex & & & & & & & & & $0,009^{*}$ \\
\hline Male & \multicolumn{2}{|c|}{26} & \multicolumn{2}{|c|}{17.9} & 119 & & \multicolumn{2}{|l|}{82.1} & \\
\hline Female & \multicolumn{2}{|c|}{35} & \multicolumn{2}{|c|}{32.1} & 74 & & \multicolumn{2}{|l|}{67.9} & \\
\hline Small for gestational at birth & & & & & & & & & $<0.0001^{*}$ \\
\hline Yes & \multicolumn{2}{|c|}{34} & \multicolumn{2}{|c|}{85.0} & 6 & & \multicolumn{2}{|l|}{15.0} & \\
\hline No & \multicolumn{2}{|c|}{27} & \multicolumn{2}{|c|}{12.6} & 187 & & \multicolumn{2}{|l|}{87.4} & \\
\hline Late-onset sepsis & & & & & & & & & $0.004^{*}$ \\
\hline Yes & \multicolumn{2}{|c|}{23} & \multicolumn{2}{|c|}{37.7} & 38 & & \multicolumn{2}{|l|}{62.3} & \\
\hline No & \multicolumn{2}{|c|}{38} & \multicolumn{2}{|c|}{19.7} & 155 & & \multicolumn{2}{|l|}{80.3} & \\
\hline Bronchopulmonary dysplasia & & & & & & & & & $0.269^{*}$ \\
\hline Yes & s & & 33 & & 18 & & 66.7 & & \\
\hline No & 5 & & 23 & & 162 & & 76.4 & & \\
\hline Red blood cell concentrate & & & & & & & & & $0.069^{*}$ \\
\hline Yes & 2 & & 31 & & 58 & & 69.0 & & \\
\hline No & 3 & & 20 & & 135 & & 79.4 & & \\
\hline & & & & auterine gr & owth restri & ction & & & \\
\hline Variables & & & Yes & & & & No & & $p$-value \\
\hline & Mean & SD & Median & $\mathrm{P}_{25}-\mathrm{P}_{75}$ & Mean & SD & Median & $\mathrm{P}_{25}-\mathrm{P}_{75}$ & \\
\hline Gestational age (weeks, days) & -- & & 33.1 & $31.4-34.4$ & -- & & 33.0 & $30.1-34.3$ & $0.142^{* *}$ \\
\hline Birth weight (g) & $1,498.70$ & 366.90 & -- & -- & $1,919.10$ & 685.30 & -- & -- & $<0.0001^{* * *}$ \\
\hline Birth weight Z-score & -1.38 & 0.71 & -- & -- & -0.01 & 0.61 & -- & -- & $<0.0001^{* * *}$ \\
\hline Hospital stay (days) & -- & -- & 27.0 & $13.0-46.5$ & -- & -- & 14.0 & $8.0-35.5$ & $<0.004^{* *}$ \\
\hline Days of mechanical ventilation & -- & -- & 7.0 & $1.0-14.0$ & -- & -- & 4.0 & $1.0-14.0$ & $0.121^{* *}$ \\
\hline Days of oxygen therapy & -- & -- & 4.0 & $1.5-25.0$ & -- & -- & 4.5 & $1.0-15.8$ & $0.805^{* *}$ \\
\hline Days at start of enteral diet & -- & -- & 3.0 & $1.3-5.0$ & -- & -- & 2.0 & $1.0-3.0$ & $0.003^{* *}$ \\
\hline Days at start of parenteral nutrition & -- & -- & 3.0 & $2.0-5.0$ & -- & -- & 3.0 & $2.0-4.0$ & $0.204^{* *}$ \\
\hline Days at start of adequate enteral intake & -- & -- & 19.0 & $11.3-29.8$ & - & -- & 14.0 & $7.0-21.0$ & $0.001^{* *}$ \\
\hline Days without enteral diet & -- & -- & 4.0 & $2.0-8.5$ & -- & -- & 2.0 & $1.0-4.0$ & $<0.0001^{* *}$ \\
\hline CA at discharge (weeks, days) & - & -- & 37.2 & $36.0-39.0$ & -- & -- & 35.5 & $34.6-37.0$ & $<0.0001^{\star *}$ \\
\hline Weight at discharge (g) & $1,886.90$ & 266.30 & -- & -- & $2,312.20$ & 486.70 & -- & -- & $<0.0001^{* *}$ \\
\hline Weight Z-score at discharge & -2.84 & 0.89 & -- & -- & -0.85 & 0.69 & -- & -- & $<0.0001^{* * *}$ \\
\hline
\end{tabular}

Note: ${ }^{*} p$-value according to Pearson's Chi-square test; ${ }^{* *} p$-value according to Mann-Whitney test; ${ }^{* * *} p$-value according to the Student's $t$ test. Results expressed as number (\%). The percentage of the categories refers to the total number of valid answers. Missing data was not considered. Significance level: $p<0.05$.

SD: Standard Deviation; CA: Corrected Age.

Extrauterine grown restriction prevalence in the sample was $24.0 \%$, and being small for gestational age at birth increased the likelihood of EUGR by 6.14 times, while each day without enteral diet increased its likelihood by $8.0 \%$. In a Brazilian study, de Lima et al. ${ }^{15}$ found that EUGR affects $26.0 \%$ of premature infants, and small for gestational age at birth has more impact than any other variable. Gianini et al. ${ }^{28}$ also associated small for gestational age at birth with EUGR. Other studies have also found this association, but the EUGR rates varied from 16.0 to $63.0 \%{ }^{29-32}$. Shan et al. ${ }^{32}$ found EUGR in $44.0 \%$ to $62.2 \%$ of premature infants.

In this study $85 \%$ of the small for gestational age -at-birth infants had EUGR at 
Table 3. Variables in the final multivariate Poisson regression model for the outcome extrauterine growth restriction and their distributions according to gestational age strata. Viçosa (MG), Brazil, 2008-2010.

\begin{tabular}{|c|c|c|c|c|c|c|c|}
\hline Variables & & $P R$ & \multicolumn{4}{|c|}{$95 \% \mathrm{Cl}$} & $p$-value \\
\hline SGA at birth & & 6.14 & \multicolumn{4}{|c|}{$3.33-11.33$} & $<0.001$ \\
\hline \multirow[t]{3}{*}{ Days without enteral diet } & & 1.08 & \multicolumn{4}{|c|}{$1.04-1.13$} & $<0.010$ \\
\hline & \multicolumn{2}{|c|}{ GA $<28$ weeks $^{a}$} & \multicolumn{2}{|c|}{ GA 28-31 weeks ${ }^{\mathbf{b}}$} & \multicolumn{2}{|c|}{ GA 32-36 weeks ${ }^{c}$} & \multirow{2}{*}{$p$-value } \\
\hline & $\mathrm{n}$ & $\%$ & $\mathrm{n}$ & $\%$ & $n$ & $\%$ & \\
\hline SGA at birth & & & & & & & $0.001^{*}$ \\
\hline Yes & -- & -- & 4 & 10.0 & 36 & 90.0 & \\
\hline \multirow[t]{2}{*}{ No } & 21 & 9.8 & 71 & 33.2 & 122 & 57.0 & \\
\hline & Median & $\mathrm{P}_{25}-\mathrm{P}_{75}$ & Median & $P_{25}-P_{75}$ & Median & $P_{25}-P_{75}$ & \\
\hline Days without enteral diet & 5.5 & $3.3-10.0$ & 3.0 & $2.0-6.0$ & 2.0 & $1.0-4.0$ & $<0.0001^{*}$ \\
\hline
\end{tabular}

Note: ${ }^{*} p$-value according to Fisher's exact test, testing $b$ and $c$ (it was not possible to test a for association because of its zero frequency); ${ }^{* *} p$-value according to the Kruskal-Wallis test. The model included the following variables with $p<0.20$ in bivariate analysis: Small for Gestational Age (SGA) at birth, sex, neonatal sepsis, red blood cell concentrate, age at start of enteral diet, age at start of adequate enteral intake, and days without enteral diet; the variable gestational age was a confounding factor. Results expressed as number (\%). The percentage of categories refers to the total number of valid answers. Missing data were not considered. Significance level: $p<0.05$.

PR: Prevalence Ratio; 95\% Cl: 95\% Confidence Interval; GA: Gestational Age.

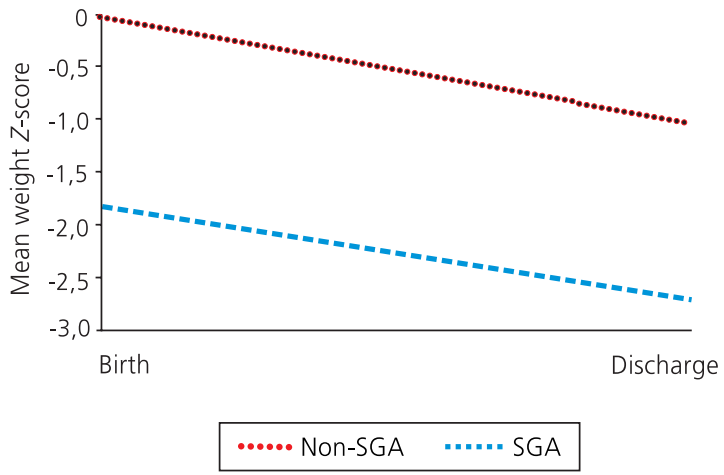

Figure 2. Weight Z-scores during the hospital stay. Viçosa (MG), Brazil, 2008-2010.

Note: Small for Gestational Age (SGA) infants lost less weight Z-score (difference of 0.93) while non-SGA infants lost more weight (difference of 1.01) - Student's $t$ test; $p<0.001$.

discharge. Data from the Neonatal Surveys Network of the National Institute of Child and Human Development (NICHD) found that 16\% of premature infants were small for gestational age at birth, and $89 \%$ of these infants continued small at corrected age 36 weeks, corroborating the association between EUGR and small for gestational age at birth ${ }^{31,33}$.

In a previous study with this population, Freitas et al. ${ }^{34}$ found a frequency of small for gestational age at birth of $11.3 \%$ using as reference Lubchenco's et al. ${ }^{35}$ curves, confirming the association between small for gestational age at birth and higher odds of death, which was corroborated by Larroque et al. ${ }^{36}$ However, if the data were revisited and the Fenton \& $\mathrm{Kim}^{9}$ curves were used, this prevalence would increase to $17.7 \%$, which is important when considering the associations between small for gestational age at birth and the outcomes EUGR and death.

The variation in EUGR prevalence can be explained by sample differences, use of different reference curves, and use of different cut-offs to characterize the outcome. Although the American Academy of Pediatrics recommends that extrauterine growth rate should aim to equal intrauterine growth rate of a premature infant with same gestational age ${ }^{2,29}$, the postnatal growth curves seem more appropriate to follow their growth ${ }^{37}$, and currently, the Fenton \& $\mathrm{Kim}^{9}$ and Fenton et al. ${ }^{10}$ curves approach the standard for classifying and following newborns until the corrected age of 50 weeks ${ }^{11}$. Lima et al. ${ }^{15}$ also disagree with the American Academy of Pediatrics recommendations.

Extrauterine grown restriction was significantly associated with longer time without enteral diet. The median ages at start of parenteral and enteral nutrition were higher than the recommended values - early use of parenteral 
nutrition in the first hours of life and minimum enteral diet on the first or second day ${ }^{38}$. However, adherence to the clinical protocols remains far from the ideal even in developed countries ${ }^{38,39}$. Despite the absence of association in the present study, nutritional practices influence the growth rate of premature infants ${ }^{7,40,41}$, and recommendations should be followed because they are widely supported by scientific evidence.

The study morbidities did not affect premature infant growth, disagreeing with Gianini et $a^{28}$. Other researchers have found that morbidities and care practices during hospital stay, including nutritional practices, influenced newborn growth rate $21,22,38,40,41$, and emphasized the importance of providing adequate amounts of energy and proteins ${ }^{13,42}$.

Growth rate and dynamics during hospital stay are under study. It is fact that the first two weeks of life represent a critical occasion in premature infant growth ${ }^{13,42}$ and that inadequate growth during the first weeks after birth can be a marker of EUGR ${ }^{3}$.

The weight curves showed that the median weight of infants with gestacional age $<32$ weeks tended to recover by 13 days of life. Moreover, moderately premature infants (gestational age at birth between 32 and 36 weeks) tended not to recover the median birth weight until the twentieth or twenty-seventh postnatal day. According to the literature, premature infants need 8 to 24 days to recover their birth weight ${ }^{28,43}$. Initial weight loss, which usually occurs between the fourth and ninth postnatal day, especially on the first five days, is followed by an early growth peak, with growth rates that tend to mimic intrauterine rates from the second week onward $33,43,44$.

The results may have been influenced by the absence of small for gestational age in infants with gestational age $<28$ weeks due to higher mortality as gestational age decreased. Although gestational age did not remain in the final model, it was associated with EUGR in bivariate analysis, that is, as gestational age increased, the frequency of EUGR also increased, which may in part explain the behavior of the study curves.

There is evidence that the incidence of EUGR increases as gestational age and birth weight decrease, given that smaller premature infants lose more weight and take longer to regain the weight, and that as gestational age decreases, nutritional requirements increase and achievement of satisfactory growth rates becomes less likely. In other words, the chance of reaching a normal weight decreases as the time to achieve a normal growth rate increases ${ }^{2,41,42,45-47}$. On the other hand, Shan et al..$^{32}$ associated EUGR with an increase in gestational age, which agrees with our results.

The smaller weight Z-score loss among small for gestational age infants allows one to understand the occurrence of EUGR in non- small for gestational age infants and to elucidate the impact of longer periods without enteral diet on EUGR genesis. Lima et al. ${ }^{15}$ also found similar results for weightZ-scores. Embleton et al. ${ }^{48}$ reinforce the multiplicity of factors involved in the development of EUGR and associate the accumulation of nutritional deficits in the first weeks after birth to nutritional practices, resulting in EUGR.

On the other hand, Ornelas et al. ${ }^{49}$ found that the extrauterine growth rates of premature small for gestacional age and appropriate for gestational age infants differ and that small for gestational age infants have less inclined growth curves than appropriate for gestational age until the fortieth week. Ehrenkranz et al. ${ }^{50}$ reported that appropriate for gestational age infants and infants who did not develop severe morbidities had higher growth rates.

Cooke et al. ${ }^{2}$ and Cooke ${ }^{51}$ affirms that extrauterine growth is influenced by a complex interaction of factors, that it is difficult to establish proper nutrition in ill and clinically unstable premature infants, and that when the energy and protein supplies are based on birth weight, the infants receive less food than they should.

In summary, the study showed that: $24.0 \%$ of the study premature infants developed EUGR; 
small for gestational age and more time without enteral diet were associated with higher odds of developing EUGR; EUGR affected $85.0 \%$ of small for gestational age infants; $15.7 \%$ of the study sample was born small for gestational age and 24.0\% developed EUGR; 55.3 and $44.3 \%$ of EUGR cases involved infants who were and were not small for gestational age at birth, respectively; moderately premature infants tended not to regain their median birth weight by the third postnatal week, and this stratum contained a higher concentration of small for gestational age infants; and non- small for gestational age infants lost more weight Z-score between birth and discharge than small for gestational age infants, reinforcing the role of nutritional practices.

The present study emphasizes the need of more studies of moderately premature infants, which include most infants born before the thirtyseventh week of gestation. The limitations include the retrospective characteristic of the study, which entails information bias (medical records) and the lack of further nutritional details.

\section{CONCLUSION}

Extrauterine growth restriction is a problem in premature infants, which is associated with small for gestational age at birth and longer periods without enteral diet. However, EUGR genesis is multifactorial, and the factors involved remain unknown. Based on the study results, we suggest more prospective studies with premature infants of all gestational ages and point out that the dissemination of information and implementation of good care practices to improve nutrient supply, individualized for small for gestational age infants, can minimize the problem.

\section{CONTRIBUTIORS}

BAC FREITAS conducted the analyses and wrote the article. SE PRIORE, LM LIMA, and SCC FRANCESCHINI supervised the analyses and reviewed the article.

\section{REFERE N CES}

1. Barros FC, Victora CG, Barros AJ, Santos IS, Albernaz E, Matijasevich A, et al. The challenge of reducing neonatal mortality in middle-income countries: Findings from three Brazilian birth cohorts in 1982, 1993, and 2004. Lancet. 2005; 365(9462):847-54. http://dx.doi.org/10.1016/ S0140-6736(05)71042-4

2. Cooke RJ, Ainsworth SB, Fenton AC. Postnatal growth retardation: $A$ universal problem in premature infants. Arch Dis Child Fetal Neonatal. 2004; 89(5):F428-F30. http://dx.doi.org/10.1136/ adc.2001.004044

3. Rugolo LMSS, Bentlin MR, Rugolo Junior A, Dalben I, Trindade CEP. Crescimento de prematuros de extremo baixo peso nos primeiros dois anos de vida. Rev Paul Pediatr. 2007; 25(2):142-9.

4. Rugolo LM. Crescimento e desenvolvimento a longo prazo do prematuro extremo. J Pediatr. 2005; 81(1 Suppl.):S101-10.

5. Madden J, Kobaly K, Minich N, Schluchter M, Wilson-Costello D, Hack M. Improved weight attainment of extremely low-gestational-age infants with bronchopulmonary dysplasia. J Perinatol. 2010; 30(2):103-11. http://dx.doi.org/10.1038/jp. 2009.142

6. Jobe $A H$. Let's feed the premature lung. J Pediatr. 2006; 82(3):165-6.

7. Anchieta LM, Xavier CC, Colosimo EA. Crescimento de recém-nascidos pré-termo nas primeiras 12 semanas de vida. J Pediatr. 2004; 80(4):267-76. http://dx.doi.org/10.1590/S0021-755720040005 00005

8. Anchieta LM, Xavier CC, Colosimo EA. Velocidade de crescimento de recém-nascidos pré-termo adequados para a idade gestacional. J Pediatr. 2004; 80(5):417-24.

9. Fenton TR, Kim JH. A systematic review and metaanalysis to revise the Fenton growth chart for premature infants. BMC Pediatr. 2013; 13:59. http:// dx.doi.org/10.1186/1471-2431-13-59

10. Fenton TR, Nasser R, Eliasziw M, Kim JH, Bilan D, Sauve R. Validating the weight gain of premature infants between the reference growth curve of the fetus and the term infant. BMC Pediatr. 2013; 13(1):92. http://dx.doi.org/10.1186/1471-2431-13-92

11. Secção de Neonatologia da Sociedade Portuguesa de Pediatria. Recomendação de curvas de crescimento para crianças nascidas pré-termo. Acta Pediatr Port. 2012; 44(2):94-9.

12. Coverston $C R$, Schwartz R. Extrauterine growth restriction: A continuing problem in the NICU. Am J Matern Child Nurs. 2005; 30(2):101-6. 
13. Brasil. Ministério da Saúde. Secretaria de Atenção à Saúde. Atenção à saúde do recém-nascido: guia para os profissionais de saúde. Brasília: Ministério da Saúde; 2011.

14. Engle WA, Kominiarek MA. Late premature infants, early term infants, and timing of elective deliveries. Clin Perinatol. 2008; 35(2):325-41. http://dx.doi. org/10.1016/j.clp.2008.03.003

15. Lima PA, Carvalho M, Costa AC, Moreira ME. Variables associated with extra uterine growth restriction in very low birth weight infants. J Pediatr. 2014; 90(1):22-7. http://dx.doi.org/10.1016/j.jped. 2013.05.007

16. Institute of Medicine. Premature birth: Causes, consequences, and prevention. Washington (DC): National Academy of Sciences; 2007 [cited 2014 May 2]. Available from: http://www.nap.edu/ catalog/11622.html

17. Ballard JL, Khoury JC, Wedig K, Wang I, EilersWalsman BL, Lipp R. New Ballard Score, expanded to include extremely premature infants. J Pediatr. 1991; 119(3):417-23.

18. Rugolo LM. Crescimento e desenvolvimento a longo prazo do prematuro extremo. J Pediatr. 2005; 81(1 Supl.):S101-S10.

19. Lee PA, Chernausek SD, Hokken-Koelega AC, Czernichow P. International Small for Gestational Age Advisory Board consensus development conference statement: Management of short children born small for gestational age, April 24October 1, 2001. Pediatrics. 2003; 111(6 Pt. 1): 1253-61.

20. Fenton TR, Sauve RS. Using the LMS method to calculate Z-scores for the Fenton premature infant growth chart. Eur J Clin Nutr. 2007; 61(12):1380-5. http://dx.dor.org/10.1038/sj.ejcn.1602667

21. World Health Organization. WHO child growth standards: Length/height-for-age, weight-for-age, weight-for-length, weight-for height and body mass index-for-age: Methods and development. Geneva: WHO; 2006.

22. Jobe $A H$, Bancalari E. Bronchopulmonary dysplasia. Am J Respir Crit Care Med. 2001; 163(7):1723-9.

23. Agência Nacional de Vigilância Sanitária. Neonatologia: critérios nacionais de infecções relacionadas à assistência à saúde. Brasília: Anvisa; 2010.

24. Sisk PM, Lovelady CA, Gruber KJ, Dillard RG, O'Shea TM. Human milk consumption and full enteral feeding among infants who weigh $<1250$ grams. Pediatrics. 2008; 121(6):e1528-e33. http://dx.doi. org/10.1542/peds.2007-2110

25. Premji SS, Fenton TR, Sauve RS. Higher versus lower protein intake in formula-fed low birth weight infants. Cochrane Database Syst Rev. 2011;
(2):CD000341. http://dx.doi.org/10.1002/146518 58.CD003959.pub1

26. Barros AJ, Hirakata VN. Alternatives for logistic regression in cross-sectional studies: An empirical comparison of models that directly estimate the prevalence ratio. BMC Med Res Methodol. 2003; 3:21. http://dx.doi.org/10.1186/1471-2288-3-21

27. Ehrenkranz RA, Dusick AM, Vohr BR, Wright LL, Wrage LA, Poole WK. Growth in the neonatal intensive care unit influences neurodevelopmental and growth outcomes of extremely low birth weight infants. Pediatrics. 2006; 117(4):1253-61. http://dx.doi.org/10.1542/peds.2005-1368

28. Gianini NM, Vieira AA, Moreira ME. Avaliação dos fatores associados ao estado nutricional na idade corrigida de termo em recém-nascidos de muito baixo peso. J Pediatr. 2005; 81(1):34-40.

29. De Curtis M, Rigo J. Extrauterine growth restriction in very-low-birthweight infants. Acta Paediatr. 2004; 93(12):1563-8.

30. Sakurai M, Itabashi K, Sato Y, Hibino S, Mizuno K. Extrauterine growth restriction in premature infants of gestational age $<$ or $=32$ weeks. Pediatr Int. 2008; 50(1):70-5. http://dx.doi.org/10.1111/j.14 42-200X.2007.02530.x

31. Clark RH, Thomas P, Peabody J. Extrauterine growth restriction remains a serious problem in prematurely born neonates. Pediatrics. 2003; 111(5 Pt. 1):986-90.

32. Shan HM, Cai W, Cao Y, Fang BH, Feng Y. Extrauterine growth retardation in premature infants in Shanghai: A multicenter retrospective review. Eur J Pediatr. 2009; 168(9):1055-9. http:// dx.doi.org/10.1007/s00431-008-0885-9

33. Dusick AM, Poindexter BB, Ehrenkranz RA, Lemons JA. Growth failure in the premature infant: Can we catch up? Semin Perinatol. 2003; 27(4):302-10.

34. Freitas BAC, Sant'Ana LFR, Longo GZ, SiqueiraBatista R, Priore SE, Franceschini SCC. Características epidemiológicas e óbitos de prematuros atendidos em hospital de referência para gestante de alto risco. Rev Bra Ter Intensiva. 2012; 24(4):386-92.

35. Lubchenco LO, Hansman C, Dressler M, Boyd E. Intrauterine growth as estimated from liveborn birth-weight data at 24 to 42 weeks of gestation. Pediatrics. 1963; 32(5):793-800.

36. Larroque B, Breart G, Kaminski M, Dehan M, Andre $M$, Burguet $A$, et al. Survival of very premature infants: Epipage, a population based cohort study. Arch Dis Child Fetal Neonatal Ed. 2004; 89(2):F139-44.

37. Cruz ACS, Falcão MC, Ramos JLA. Análise crítica do uso de curvas de crescimento intra-uterino no período neonatal. Rev Bra Nutr Clin. 2006; 21(3):198-203. 
38. Ziegler EE. Meeting the nutritional needs of the low-birth-weight infant. Ann Nutr Metab. 2011; 58(Suppl. 1):8-18. http://dx.doi.org/10.1159/00 0323381

39. Ehrenkranz RA, Das A, Wrage LA, Poindexter BB, Higgins RD, Stoll BJ, et al. Early nutrition mediates the influence of severity of illness on extremely LBW infants. Pediatr Res. 2011; 69(6):522-9. http:// dx.doi.org/10.1203/PDR.0b013e318217f4f1

40. Niklasson A, Engstrom E, Hard AL, Wikland KA, Hellstrom A. Growth in very premature children: A longitudinal study. Pediatr Res. 2003; 54(6):899-905. http://dx.doi.org/10.1203/01.PDR.0000091287. 38691.EF

41. Saluja S, Modi M, Kaur A, Batra A, Soni A, Garg P, et al. Growth of very low birth-weight Indian infants during hospital stay. Indian Pediatr. 2010; 47(10):851-6.

42. Ernst KD, Radmacher PG, Rafail ST, Adamkin DH. Postnatal malnutrition of extremely low birthweight infants with catch-up growth postdischarge. J Perinatol. 2003; 23(6):477-82. http://dx.doi.org/ 10.1038/sj.jp.7210974

43. Silveira RC, Procianoy RS. Crescimento nos primeiros anos de vida de recém-nascidos de muito baixo peso. In: Procianoy RS, Leone CR, editores. Programa de Atualização em Neonatologia (PRORN)/Sociedade Brasileira de Pediatria. Porto Alegre: Artmed; 2010. p.49-86.

44. Uliani ACCA, Carvalho R, Filho AAB. Evolução ponderal de recém-nascidos de muito baixo peso. J Pediatr. 1996; 72(6):388-93.
45. Cooke RJ, Embleton ND. Feeding issues in premature infants. Arch Dis Child Fetal Neonatal Ed. 2000; 83(3):F215-8.

46. Bertino E, Coscia A, Mombro M, Boni L, Rossetti $G$, Fabris $C$, et al. Postnatal weight increase and growth velocity of very low birthweight infants. Arch Dis Child Fetal Neonatal. 2006; 91(5):F349-F56. http//:dx.doi.org/10.1136/adc.2005.090993

47. Evans RA, Thureen P. Early feeding strategies in premature and critically ill neonates. Neonatal Netw. 2001; 20(7):7-18.

48. Embleton NE, Pang N, Cooke RJ. Postnatal malnutrition and growth retardation: An inevitable consequence of current recommendations in premature infants? Pediatrics. 2001; 107(2):270-3.

49. Ornelas SL, Xavier CC, Colosimo EA. Crescimento de recém-nascidos pré-termo pequenos para a idade gestacional. J Pediatr. 2002; 78(3):230-6.

50. Ehrenkranz RA, Younes N, Lemons JA, Fanaroff AA, Donovan EF, Wright LL, et al. Longitudinal growth of hospitalized very low birth weight infants. Pediatrics. 1999; 104(2 Pt.1):280-9.

51. Cooke R. Postnatal growth in premature infants: Have we got it right? J Perinatol. 2005; 25(Suppl. 2):S12-4. http://dx.doi.org/10.1038/sj.jp.7211310

Received: November 13, 2014 Final version: August 17, 2015 Approved: September 4, 2015 